\title{
Communication
}

\section{The Modern Phosphorus Sustainability Movement: A Profiling Experiment}

\author{
Andrea E. Ulrich ${ }^{1,2, *}$ and Ewald Schnug ${ }^{3}$ \\ 1 Institute for Environmental Decisions (IED), Natural and Social Science Interface, ETH Zurich, \\ Universitätsstrasse 22, 8092 Zurich, Switzerland \\ 2 Institute for Agricultural Sciences, Plant Nutrition, ETH Zurich, Eschikon 33, 8315 Lindau, Switzerland \\ 3 Institute of Crop and Soil Science, Federal Research Center for Cultivated Plants, Julius Kühn-Insitute, \\ Bundesallee 50, 38116 Braunschweig, Germany; E-Mail: pb@jki.bund.de
}

* Author to whom correspondence should be addressed; E-Mail: andrea.ulrich@env.ethz.ch; Tel.: +41-44-632-9318; Fax: +41-44-632-1029.

Received: 31 May 2013; in revised form: 18 September 2013 / Accepted: 17 October 2013 /

Published: 25 October 2013

\begin{abstract}
Since the "peak phosphorus" concept emerged in 2007, concerns about the future availability of phosphate rock have funneled into a growing number of actions, often in the form of new and innovative platforms focusing on phosphorus sustainability. This trend seems to continue on different levels and in different formats, which makes the landscape of activities increasingly blurred and complex. This article considers the emerging phase of the modern phosphorus sustainability movement. It provides a first profiling overview of platforms working towards more sustainable production, consumption, and reuse of phosphorus $(\mathrm{P})$ within the frame of securing global food production and environmental quality. The aim is to gain a better understanding of the movement, pertinent literature, the problem sphere itself, and of forms of possible engagement. Major barriers and opportunities inherent in the various approaches are discussed. It is concluded that overarching coordination will be necessary to improve future planning and priority setting for sustainability strategies.
\end{abstract}

Keywords: peak phosphorus; food security; sustainable development; fertilizers; global science diplomacy; research management 


\section{Introduction}

Since 2008, a series of multi-stakeholder platforms concerned with meaningfully and comprehensively addressing different (or possibly all) key aspects of the unsustainable production, consumption, and reuse of phosphorus $(\mathrm{P})$ within the frame of securing global food production and environmental quality have emerged. The diverse pool of societal actors - science, industry, business, and policy making - initiated a large number of events that promote transitions toward use, reuse, and management regimes of phosphorus that are more effective, efficient, and equitable. This rise in collaborative research on challenges and opportunities surrounding phosphorus sustainability or security is attended by an expanding body of literature. From 2009 to 2012 , more than 40 papers have been published taking into account phosphorus scarcity promulgated by Cordell, Drangert, and White [1]. Particularly, the concept of "peak phosphorus," suggesting that global phosphate rock production might reach a climax around 2030 and irretrievably decline afterwards, received wide attention in the media and within a sizeable group of stakeholders from academia, industry, governments, and non-profit organizations. As platforms and organized activities in the field continue to grow and multiply worldwide-reflected e.g., by the launch of the European Phosphorus Platform in March 2013 - an increasingly complex landscape is being created. This article confronts this complexity in addressing questions of movement genesis, geography, and "who is who". As such, the profiling exercise also places itself in the broader debate of large-scale international collaboration on global issues related to their opportunities and challenges [2,3].

This article starts from the premise that an overview of the numerous but fragmented initiatives seeking to improve our joint knowledge on improved phosphorus management through research, development, new policies and technologies will be helpful for e.g., scientists, resource managers, and decision-makers interested in following the field's progress, enhancing current efforts, or seeking to engage more actively. The purpose is to provide a comprehensive perspective on what this paper addresses as the modern phosphorus sustainability movement (Movement as "organized effort to promote or attain an end" [4]). by (i) reviewing major initiatives, their activities, key events, and publications; and (ii) discussing opportunities and challenges of these approaches. The profiling experiment aims to fill a critical void in raising awareness how the sustainable phosphorus movement started in the $21^{\text {st }}$ century, how far it has come, and where it's future may lead. It is hoped that this may launch a dialogue on how to better connect the presented initiatives. However, the paper does not include a deep analysis or comparison between initiatives, except when required. Although the authors acknowledge the rich history of past research concerned with phosphorus, and existing efforts concerned with specific aspects of the phosphorus supply chain, the scope is limited to those initiatives founded after 2007 that play a visible role in the current phosphorus sustainability debate.

The article is organized as follows: The first section gives a brief account of the origin of the reemerging phosphate supply anxiety-the underlying premise being that phosphate rock depletion concerns coupled with the food and commodity crisis in 2007/2008 are the vantage point. The second section presents major platforms, summarizes key characteristics, and identifies common denominators. After reflection upon developments, the last section discusses opportunities and challenges inherent in the collaborative approaches. In conclusion, it is argued that overarching coordination of the various initiatives can provide an overlooked synergistic effect for long-term change. 


\section{Phosphorus Background, a Brief "Peak P" Research Genesis and Geography}

Phosphorus is one of the macronutrients essential for crop growth. Largely derived from mined phosphate rock, it is crucial to fertilizer application worldwide, and hence, to food security. While the amount and composition of fertilizer compounds required for soil fertility can vary widely from one region and production system to another, in general, global application rates have increased greatly since the middle of the last century. This resulted in a food production level that allowed for unprecedented population growth. While in the past, farmers relied on organic input in the form of, e.g., bone meal, fish scrap, guano, animal dung, or night soils to achieve a permanent agriculture [5], nutrients that feed the modern agricultural system today are derived from large-scale industrial manufacturing processes that depend on considerable resources and energy input - with significant environmental feedbacks. As for any resource, the question of supply security is a complex matrix of dynamic factors related to striking a balance between inter alia physical availability (i.e., geological abundance), accessibility (e.g., price, markets, technology, infrastructure), and demand-supply mechanisms. In terms of physical availability, Nitrogen $(\mathrm{N})$ can be obtained in large quantities from the atmosphere via the Haber-Bosch process, and world resources of Potash (K) amount to 250 billion tons [6]. In comparison, the modern source of phosphate fertilizers in agriculture is phosphoric acid, which is derived from phosphate rock and sulfuric acid. While sulfuric acid is largely produced during fossil fuel processing and reserves are deemed adequate for the foreseeable future [7], concerns about phosphate rock's availability and depletion of high-grade deposits have emerged on the global stage during a time when fertilizer commodity and food prices soared [8].

In August 2007, Déry and Anderson [9] published a study entitled Peak phosphorus on the popular Energy Bulletin online platform concerned with energy supply security and peak oil. From calculations based on the Hubbert peak oil analysis [10], the authors concluded that the USA, historically the world leader in overall phosphate rock production, had reached its potential production peak in 1988. They further concluded that a world peak had possibly occurred around 1989. Both conclusions can be misleading. According to data from the USA Geological Survey, a peak in USA production has, from a 2013 standpoint, occurred in 1980 with a total rock output of 54 million metric tons. In contrast, production in 1988 only reached 45 million metric tons. A similar situation exists for global production: in 1988, world output was 162 million metric tons. This total was only reached again in 2008, with a historic high of 210 million metric tons being attained in 2012 [11]. Coinciding with the study by Déry and Anderson [9], the Story of phosphorus: Global food security and food for thought [1] was published in 2009. The authors pointed to a probable world production peak around 2030 and discussed the need to include the long-term availability of phosphate rock in global food security considerations by means of e.g., approaching improved use, reuse, and institutional measures. By September 2013, the paper had received 313 citations in SciVerse Scopus. For comparison, Hubbert's Energy from fossil fuels [12], which outlines peak fossil fuel production curves and decline, is cited 84 times (April 2013). Figure 1 depicts the paper citation analysis and the impact of $\mathrm{P}$ scarcity based on phosphate rock depletion in the scientific community. 
Figure 1. Multi-aspect citation analysis of the paper "The story of phosphorus: food security and food for thought" by Cordell, Drangert, and White [1] and impact of P scarcity in the scientific community. Figures illustrate the number of citations (2009-2012: 287), the citation distribution for the top seven source titles, the document type, and the variety of subject areas in which the paper was cited [13]. The chart "Google Scholar hits" tracks the emergence of "peak phosphorus" in the scholarly literature from June 2009 (219 hits) to March 2013 (749 hits; hits for the time period between May 2012_601 hits_-and February 2013 are extrapolated).

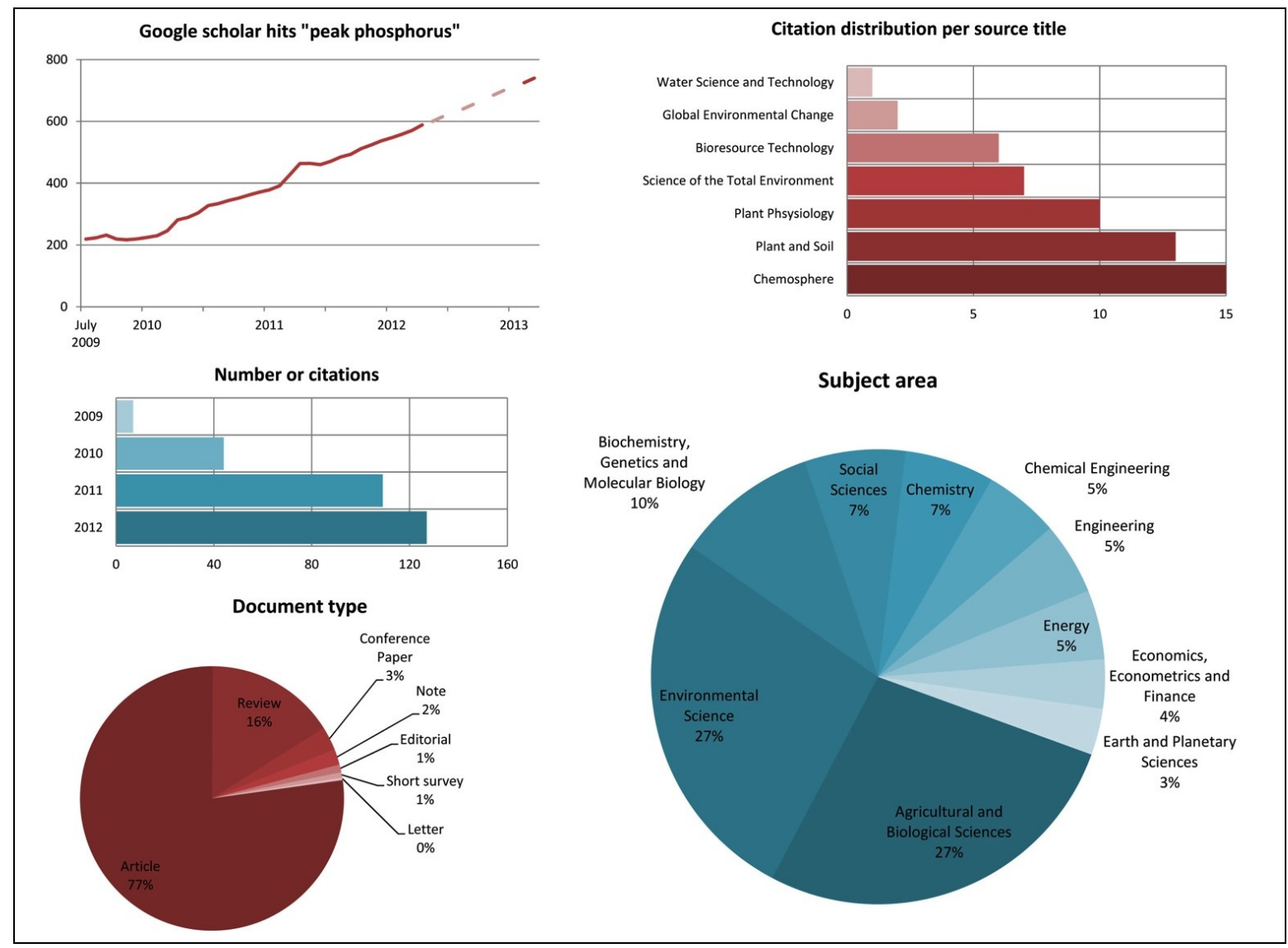

Figure 2 shows the landscape of selected key events from 2008-2014 and illustrates centers of academic P sustainability research. As can be readily seen from the combined components of Figure 1, the paper received wide attention in a variety of scientific fields. This visible diversity may serve to illustrate how broad the topic is. As citations are frequently used to indicate the impact of a study, the large and increasing number of citations the paper received in Scopus suggest a clear growth trend of the topic. Similar conclusions can be drawn from the growing list of "peak P" hits in Google Scholar. In addition, the visualization of Figure 2 gives an overview of world regions where $\mathrm{P}$ sustainability is of growing interest. Countries in red represent places that have recently held conferences or meetings relevant to P sustainability. Circles represent geographical "hot spots" in academic P sustainability research. In general, the observed patterns suggest distribution on all continents; however, there is a clear predominance in developed countries. 
Figure 2. The landscape of selected key events and university research hot spots with a focus on phosphorus sustainability, identified by citation mapping, from 2008-2014 (top 10 affiliations of authors citing Cordell, Drangert and White [1]).

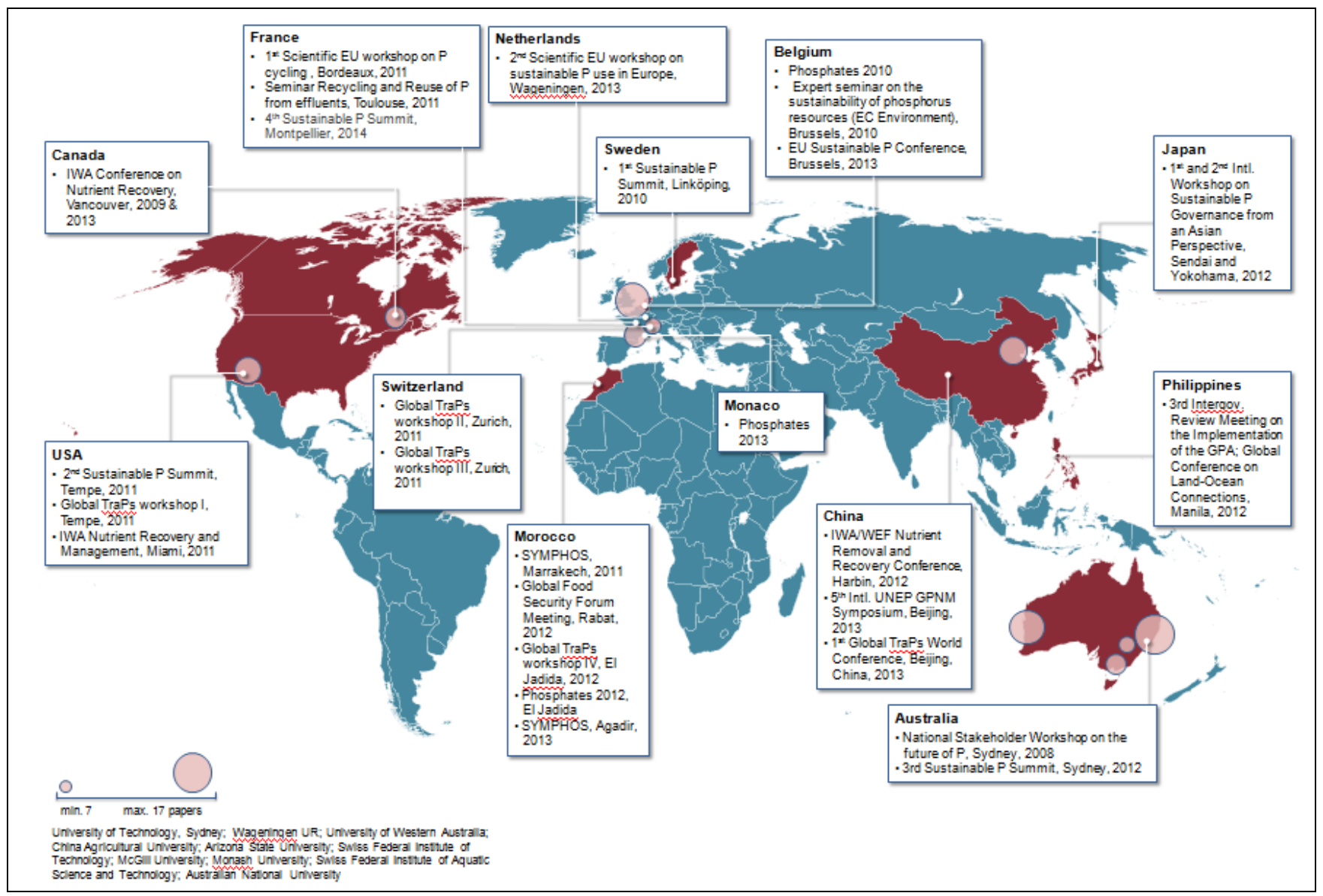

The peak P concept was contested early on by Van Kauwenbergh [14] and subsequently by other stakeholders from practice and science such as Mew [15], IFA [16], Vaccari and Strigul [17], or Scholz and Wellmer [18]. Their main arguments were largely based on a dynamic understanding of the phosphate rock resource/reserve concept or improved data. As of 2011, the USA Geological Survey estimated world phosphate rock reserves to be more than four times larger compared to the information available in 2009 [19]. While today, there appears to be no scientific evidence for the short to medium "running out" scenario on a global level as promulgated in articles such as Gilbert [20], a large amount of research paired with action, advocacy, and agenda-setting has been initiated in the field of sustainable phosphorus management since 2008, often starting from the premise of a potential imminent production peak in contrast to larger management issues along the phosphorus value chain as depicted in Figure 3. Word clouds are a simple analytical tool, which allow one to quickly grasp content. By means of quantifying the most frequent words in abstracts of one of the first publications dedicated to the emerging phosphorus challenge [21], it is found that resources and phosphate rock were clearly quoted; however, other issues such as "food", "fertilizer", "production" and "soil" were more prominent. Overall, the results reflect a diverse, broad, and relatively balanced characterization of challenging fields along the $\mathrm{P}$ cycle. 
Figure 3. World cloud of most frequent topics covered in "The phosphorus cycle". Top 20 most common words distilled from abstracts of all fifteen articles published in the Chemosphere special issue [22], 12 of which cited Cordell, Drangert and White [1], 92\% in their introduction.

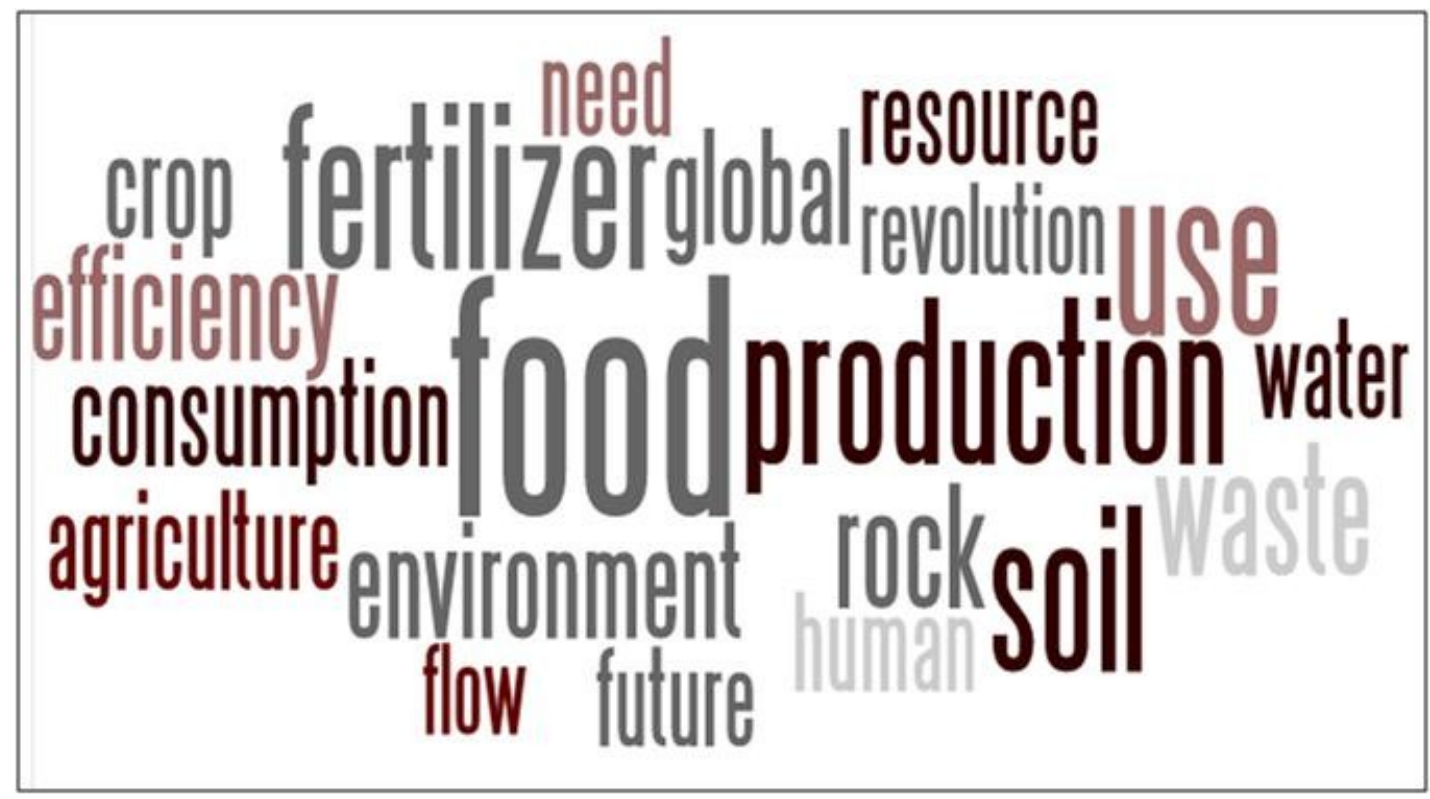

\section{Eleven Key Platforms in Detail}

To identify the emerging main protagonists in the field of phosphorus sustainability, we searched for new, voluntary, collaborative group efforts that promote improved use, reuse, and management of phosphorus since phosphate scarcity concerns emerged in 2007. Observation and literature research helped to identify further platforms. For coherence, they were analyzed according to six key characteristics: key architects, pertinent literature, key issues, goals and operational approaches, drivers, and involvement opportunities. Initiatives were divided into two groups: "national" (predominantly concerned with domestic phosphorus-related problems and solution-finding mechanisms), and "international" (engaged in the global problem definition and solution-finding processes). Within each group, initiatives were portrayed according to their formation history. For the semi-structured descriptive profiling, information available from the platform`s websites, related publications, or personal communications was synthesized. Table 1 summarizes the eleven key initiatives that were reviewed, displays selected main features, and locates them within the phosphorus lifecycle. 
Table 1. Overview of key initiatives concerned with phosphorus sustainability and related issues such as food security or dissipation (2008-2013).

\begin{tabular}{|c|c|c|c|c|c|}
\hline Action level & Initiative & Initiators & P lifecycle stage & Based in & Website \\
\hline \multicolumn{6}{|l|}{ national } \\
\hline & $\begin{array}{l}\text { Phosphorus Recycling } \\
\text { Promotion Council }\end{array}$ & $\begin{array}{l}\text { nationwide multi-stakeholder group with } \\
\text { government support }\end{array}$ & recycling & Japan & www.jora.jp/rinji/rinsigen/index.html \\
\hline & Sustainable P Initiative & $\begin{array}{l}\text { School of Life Sciences, Arizona State } \\
\text { University, Tempe, AZ }\end{array}$ & $\begin{array}{l}\text { complete cycle/production- } \\
\text { consumption/dissipation }\end{array}$ & USA & $\begin{array}{l}\text { www.sustainablep.asu.edu/home } \\
\text { www.sustainablep.wordpress.com }\end{array}$ \\
\hline & $\begin{array}{l}\text { Sustainable Phosphorus } \\
\text { Research Coordination } \\
\text { Network }\end{array}$ & $\begin{array}{l}\text { School of Life Sciences, Arizona State } \\
\text { University, Tempe, AZ }\end{array}$ & $\begin{array}{l}\text { complete cycle/production- } \\
\text { consumption }\end{array}$ & USA & http://sustainablep.asu.edu/prcn \\
\hline \multirow{2}{*}{ (C) } & Dutch Nutrient Platform & public and private Dutch organizations & complete cycle/ recycling & Netherlands & www.nutrientplatform.org \\
\hline & $\begin{array}{l}\text { Australian Sustainable } \\
\text { Phosphorus Futures Project }\end{array}$ & $\begin{array}{l}\text { Institute for Sustainable Futures, } \\
\text { University of Technology (UTS), Sydney }\end{array}$ & $\begin{array}{l}\text { complete cycle/production- } \\
\text { consumption }\end{array}$ & Australia & www.phosphorusfutures.net \\
\hline \multicolumn{6}{|l|}{ international } \\
\hline \multirow{4}{*}{ (B) } & Global Phosphate Forum & producers of detergent phosphates & production-consumption & Belgium & www.phosphate-forum.org \\
\hline & $\begin{array}{l}\text { Global Phosphorus } \\
\text { Research Initiative (GPRI) }\end{array}$ & $\begin{array}{l}\text { Institute for Sustainable Futures at the } \\
\text { University of Technology, Sydney, and } \\
\text { the Departement of Water and } \\
\text { Environmental Studies at Linköping } \\
\text { University, Sweden }\end{array}$ & $\begin{array}{l}\text { complete cycle/production- } \\
\text { consumption }\end{array}$ & Australia & www.phosphorusfutures.net \\
\hline & $\begin{array}{l}\text { UNEP Global Partnership on } \\
\text { Nutrient Management }\end{array}$ & $\begin{array}{l}\text { United Nations Environment } \\
\text { Program,Global Programme of Action } \\
\text { for the Protection of the Marine } \\
\text { Environment from Land-based Activities } \\
\text { (GPA) }\end{array}$ & $\begin{array}{l}\text { dissipation/production- } \\
\text { consumption }\end{array}$ & Kenya & www.gpa.unep.org/gpnm \\
\hline & Global Phosphorus Network & GPRI & $\begin{array}{l}\text { complete cycle/production- } \\
\text { consumption }\end{array}$ & Australia & www.globalpnetwork.net \\
\hline & $\begin{array}{l}\text { Global TraPs (Global } \\
\text { Transdisciplinary Processes } \\
\text { for Sustainable Phosphorus } \\
\text { Management) }\end{array}$ & $\begin{array}{l}\text { Chair of Natural and Social Science } \\
\text { Interface at the Swiss Federal Institute } \\
\text { of Technology (ETH), Zurich, } \\
\text { International Fertilizer Development } \\
\text { Center (IFDC), Muscle Shoals, AL }\end{array}$ & complete cycle/supply chain & $\begin{array}{l}\text { Germany, } \\
\text { USA }\end{array}$ & www.globaltraps.ch \\
\hline & Global Food Security Forum & $\begin{array}{l}\text { OCP Group (Office Cherifien des } \\
\text { Phosphates) }\end{array}$ & production-consumption & Morocco & www.globalfoodsecurityforum.com \\
\hline & $\begin{array}{l}\text { European Phosphorus } \\
\text { Platform }\end{array}$ & $\begin{array}{l}\text { European partners of the phosphorus } \\
\text { value chain }\end{array}$ & $\begin{array}{l}\text { production- } \\
\text { consumption/recycling }\end{array}$ & Netherlands & www.phosphorusplatform.org \\
\hline
\end{tabular}

\subsection{Platforms Operating on a National Level}

\subsubsection{Phosphorus Recycling Promotion Council, Japan}

The Phosphorus Recycling Promotion Council was founded in late 2008 for an unspecified period of time by seven individuals from the Japan Fertilizer and Feed Inspection Association, the Japan Soil Association, Osaka University, Tohoku University, the Japan Fertilizer and Ammonia Producers Association (JAF), the Japan Organics Recycling Organization, and the Japan Sewage Works Association. Professor Ohtake from Osaka University leads the initiative that is being funded by JAF and in 2013 included members from four government agencies (the Ministries of Economy, Agriculture, Land, and the Environment), knowledge institutions (e.g., Osaka University, Tokyo University of Agriculture, Tohoku University, Tokushima University, the National Institute of Material Science, the National Institute of Environmental Studies), industry and practice (e.g., Japan Organics Recycling Association, Japan Sewage Works Association, the Soil Association; the iron and steel industry). Driving key concerns are price considerations, both in terms of increasing national waste treatment costs as well as the 2007 and 2008 global food and fertilizer price volatility. To reach the underlying goal—strategically and sustainably manage phosphorus — council members engage in a 
variety of activities, including in-depth research on resource logistics, improved nutrient utilization, modeling phosphate flows, and phosphate recovery [23,24]. The multi-stakeholder cooperation aims to establish a well-functioning platform that enables certain knowledge gaps not only at the interface or within certain sectors, but also on the different action levels to be overcome. While strong emphasis rests on the development and implementation of cost-saving, innovative technologies [25] for recovering and recycling phosphorus, the platform also directs its efforts towards raising public awareness of the inherent links between securing phosphorus availability, soil fertility, food security, and technology improvements. Expected outcomes are stronger collaboration between the different groups concerned to work jointly towards improving the resource's governance, as well as cross-regionally, as last year's two Japan-based workshops on $P$ governance from an Asian perspective demonstrated. The platform is open for involvement along these lines.

\subsubsection{Sustainable Phosphorus Initiative (SPI), USA}

The Sustainable Phosphorus Initiative (SPI) was founded by Jim Elser, Dan Childers, Marc Edwards, and Jessica Corman of Arizona State University (USA) in 2010 and was originally driven by limnological considerations, i.e., eutrophication. It is interdisciplinary scientific in its approach to build a credible scientific consensus on the dimensions of phosphorus sustainability, as well as to mobilize a global inter- and transdisciplinary network on the issue. At its very core, the initiative aims to motivate changes on the institutional and commercial levels as well as in consumer behavior [26] to spur phosphorus conservation and recycling efforts. Key messages such as "the biggest problem you have never heard of" and "closing the human P cycle" [27] capture the inherent problems and lack of awareness of the broken phosphorus cycle [19,28,29]. SPI hosted the second Phosphorus Summit in Tempe, AZ, in January 2011. The outcome was twofold: first, the Phoenix Phosphorus Declaration, a consensus statement on global P sustainability challenges and opportunities; second, a multi-author book expected to be published in 2013 [30]. The five-year SPI sub-project Sustainable Phosphorus Research Coordination Network (RCN), which gained funding support by the USA National Science Foundation in 2012, held its kick-off in the first half of 2013. During its first phase, Working Groups will revise and analyze the first two identified Challenge Areas stated in their declaration, phosphorus efficiency and recycling, during several planned workshop meetings to be held in Washington D.C.. The second phase strives towards integrating the two subject groups. Multiple benefits are expected, ranging from new forms of cooperation between concerned parties, to robust research projects, extended communication of the problem field, and ways to approach them. The science-based, interdisciplinary platform has a strong USA focus, yet it responds to the reality of the problem's global nature by aspiring to associate international experts and leaders in the field. It is open to a wide stakeholder group.

\subsubsection{Dutch Nutrient Platform (NP), Netherlands}

The Dutch Nutrient Platform (NP), which was founded in early 2011 in the Netherlands and is presided by Eric Smaling, links different groups in the phosphorus cycle, most notably farmer associations, the water sector, industries concerned with waste handling, fertilizer producers or other phosphorus-based industries, representatives from NGOs and governments, and research centers 
within the country. More than 20 parties initially signed the Phosphate Value Chain Agreement [31] in October 2011, and participation has now risen to more than thirty organizations. This basic document of the initiative outlines its goals, namely to design and implement a cradle-to-cradle perspective on phosphorus use, recycling, and reuse. It also includes a clear statement by the Netherlands to be willing to take issues further on the European and international levels. The agreement is considered a pioneering document for nutrient management's institutionalization. The network strives to create a market for national surplus-P via recycled products by the end of 2013 by exploring different business cases and analyzing legislation challenges. Regulatory barriers that prevent innovation to take place will be identified. Further, research on phosphorus flows is being supported. Major drivers are concerns of nutrient depletion and the subsequent major global impact on food security, a substantial phosphorus-surplus resulting from a large national livestock industry, the absence of recycling in agriculture, and the significant dependence on phosphate rock imports. Smart regulation, trust building between stakeholders, and creating a safer investment space are recommended by the NP for greening the economy. The NP initiated and co-organized the European Sustainable Phosphorus Conference held in Brussels in March 2013. As a Dutch network, membership is open for Dutch organizations.

\subsubsection{Australian Sustainable Phosphorus Futures Project}

The Australian Sustainable Phosphorus Futures Project (2012-2014) is implemented by the National Strategic Phosphorus Advisory Group [32]. Led by the Institute of Sustainable Futures, the multi-stakeholder group is concerned with framing sustainable phosphorus use options in Australia to secure long-term food production. Conducting analyses of phosphorus stocks and flows [33] as well as scenarios [34] will be a major task, in addition to communicating relevant, credible, and consistent results to policy-makers. This will allow research priorities to be set and policy options to be identified. The platform was launched during the 3rd Sustainable Phosphorus Summit in Sydney, Australia (29 February-2 March 2012).

\subsection{Platforms Operating on an International Level}

\subsubsection{The Global Phosphate Forum}

The Global Phosphate Forum (GPF) is a non-profit organization formed in 2007 in Sao Paolo through the action of 13 companies from Belgium, Brazil, Germany, India, Israel, Mexico, Russia, Spain, and Venezuela. As the world association for producers of phosphates used in detergents (sodium tripolyphosphate, STPP), it functions on a voluntary and paid membership basis. Its major tasks, summarized in its Statutes [35] are to promote the use of phosphates in detergents, cleaning products, or other industrial applications apart from food or pharmaceuticals; to engage and promote a better understanding of the effects of phosphorus on the environment and recycling via communication and coordination; and representation of the collective interest of different bodies of, e.g., trade and regulation. In early 2013, the industry association included six members located in Belgium, Germany, Kazakhstan, Netherlands, Tunisia, and the USA Within the phosphorus sustainability movement, GPF is one of the sponsors of Global Phosphorus Network and a participant in the Global TraPs Project. Under its umbrella, a key activity is the provision of the SCOPE newsletter, formerly published under 
the Centre Européen d'Etudes sur les Polyphosphates (CEEP), a sector group of the former European Chemical Industry Council (Cefic), now the European Phosphoric Acid and Phosphates Producers Association (PAPA). The newsletter has been published since 1990 several times a year, with a peak output in 2011 and 2012. Given that the phosphate detergent industry landscape is changing fundamentally in Europe with the EC ban on domestic laundry and dishwasher detergents, with restrictions applying in 2013 and 2017, respectively [36], some changes in the forum's composition and activities are expected.

\subsubsection{The Global Phosphorus Research Initiative (GPRI)}

The Global Phosphorus Research Initiative (GPRI) was founded early in 2008 by the Institute for Sustainable Futures, the University of Technology, Sydney (Australia), and the Department of Thematic Studies, Water and Environmental Studies, Linköping University (Sweden) as a spring-off of the doctoral thesis Sustainability implications of global phosphorus scarcity for food security by Cordell [37]. Its main function is to provide a collaboration platform for independent research institutes worldwide. In 2009, GPRI published its Declaration on global phosphorus security. In this key document, members and affiliates of the initiative state three arguments for change: that "global phosphorus usage practices are threatening the world's future ability to produce food and are responsible for widespread eutrophication," that "a peak in global phosphate rock production is likely within the next few decades after which demand will exceed supply," and that in the face of growing environmental, economic, and ethical concerns, action, based on the principal of sustainable development, is required to achieve phosphorus security. Seen as main architects of the peak phosphorus concept and first international group advocating phosphorus security, several key publications have appeared discussing the concept, sustainability options, and ways to move forward [33,38-40]. The joint initiative expanded its membership in 2011 to also include the Stockholm Environment Institute (Sweden), the University of British Columbia (Canada), and Wageningen University (The Netherlands). The main driving force behind all activities are the limited awareness historically, current research, and the policy debate on global phosphorus scarcity that threatens agricultural food production as well as the current strategic window of opportunity to communicate the problem and advance sustainable solutions. Striving to increase knowledge in this problem field and generate sustainable solutions, the initiative consolidates expertise between its members and facilitates interdisciplinary research through an interdisciplinary research format. This was exemplified during the 2nd Sustainable P Summit in Sydney in 2012, whose outcome, a Blueprint for P security, is to be published in 2013. In addition, the group is strongly involved in raising awareness, co-developing policy recommendations, communicating results and setting an agenda for global food security. Engagement is open for independent research institutes.

\subsubsection{The Global Partnership on Nutrient Management, UNEP}

The Global Partnership on Nutrient Management (GPNM) was founded in 2009. It acts under the United Nations Environment Program (UNEP)'s Global Program of Action for the Projection of the Marine Environment from Land-based Activities (GPA). The global nutrient challenge, framed in the context of complex benefits of increasing the use of nitrogen and phosphorus and costs in terms of 
resulting environmental problems, triggered its establishment. In 2011, UNEP called attention to phosphate rock availability in its yearbook [41]. Declared goals are to reduce excess nutrient flows while not inhibiting global development [42]. The Manila Declaration [43] acknowledged the humaninduced increase of $\mathrm{P}$ and $\mathrm{N}$ into ocean. Work is planned to globally assess nutrient management policies, practices, and their multiple impacts. This will be achieved by goal-oriented global advocacy directed towards governments and stakeholders for action. GPNM provides discursive space for countries and stakeholders from all sectors to create best practices in nutrient management from a systems perspective. As outlined in their recent report Our Nutrient World [44], a viable next step will be to determine how to move forward on questions concerning the mandate and the process. Questions remain open in regard to whether an existing intergovernmental process such as IPCC should be applied or whether other forms of policy processes need to be established to allow use efficiency measures to be set. While discussions on a $20 \%$ nutrient use efficiency policy have started, no agreement could be reached so far. GPNM embraces stakeholders from national and international governing bodies, universities, and foundations, among others.

\subsubsection{The Global Phosphorus Network (GPN)}

The Global Phosphorus Network (GPN) was founded in 2011 by the University of Technology Sydney as an initiative of GPRI and is managed by Dana Cordell, Stuart White, and Tina Schmid Neset. Its membership amounts to over 500 individuals from a vast background of disciplines and stakeholder groups. Its goal is to fill the void of a missing public platform for discourse on issues related to phosphorus security via increasing scientific understanding of the issue, awareness, action, and public debate. In that sense, it provides a platform for all those interested or willing to share their expertise in finding ways to work towards phosphorus security. GPN is funded by the GPF, the Swedish Research Council FORMAS, and a Danish biotech firm.

\subsubsection{Global Traps}

The Global TraPs project ("Global Transdisciplinary Processes for Sustainable Phosphorus Management”) is an international multi-stakeholder forum which was designed and initiated by Scholz and Ulrich at the Swiss Federal Institute of Technology in Zurich from March 2010 onward [45]. The project was officially launched in February 2011 when the International Fertilizer Development Center (IFDC; Muscle Shoals, Alabama, USA) became the project's practice co-leader. At the time, IFDC had just introduced its Phosphorus Efficiency Initiative, which aims to improve the direct application of phosphate rock and to determine the global availability of phosphate rock reserves and resources [14]. Since 2013, the project has been co-lead on the science side by Frauenhofer of Germany, Europe`s largest application-oriented research organization. The original drivers for Global TraPs are found in the essentiality and criticality considerations of both the resource phosphate rock and the element phosphorus. The project is largely concerned with the long-term management of biogeochemical cycles, the challenge of closing the fertilizer loop, and a new type of sustainability learning on a global scale. In applying the supply chain perspective for case representation and establishing a human-environment systems-based transdisciplinary process, it is built to create a non-politicized and pre-competitive platform that contributes to a constructive $\mathrm{P}$ dialogue and 
sustainable management practices over its five-year lifetime (2010-2015). A project guiding question will be answered via case-study research: "What new knowledge, technologies and policy options are needed to ensure that future phosphorus use is sustainable, improves food security and environmental quality, and provides benefits for the poor?" [46]. In 2011 and 2012, four workshops were held to establish project propositions [47], agreement upon the guiding question, and case studies [48]. The first of two world conferences was held in Beijing, China, in joint partnership with the Chinese Academy of Sciences and UNEP's Global Partnership on Nutrient Management. The results of the last two years will be made available in book form in 2014 [49]. Engagement is open for science and practice representatives with an interest in phosphorus.

\subsubsection{Global Food Security Forum}

The Global Food Security Forum (GFS) was established in 2012 as an initiative of the OCP Group. OCP is a global leader in the phosphate market and works the world's largest known phosphate rock reserves, in Morocco [11]. In 2011, it started to host the by-annual International Symposium on Innovation and Technology in the Phosphate Industry. OCP contributes substantially to global food security and acknowledges its responsibility in it. Founded by organizations from six different countries (Morocco, India, Brazil, France, The Netherlands, and Sierra Leone), the forum aims to provide a meeting and communications platform for a high-level, multi-disciplinary group of global leaders in food security and organizations from a broad spectrum of society. The inaugural meeting [50] was held in Rabat, Morocco, which almost 300 individuals, more than $70 \%$ from the South, attended. While the initiative not only has a stake in phosphorus, but also in global food security, it spans the spectrum of interaction further. Its strong drive to larger membership from the South makes it, both in terms of origins and outlook, the first high-profile South initiative. This is an important contribution to a more balanced North-South interaction. The main purpose of the initiative is to "identify and support promising innovations, approaches and partnerships to assure food security at the local, national and global levels" [51]. At the center of efforts rests the advancement of integrating the triple-bottom line, smart investment, and advocacy to secure global food security on a global level, yet particularly for those the least resilient. GFS is a high-profile solution-oriented platform with more than 200 key food security stakeholders, striving for partnership with all concerned or affected parties. It operates via working groups that have a clear research and development agenda, supporting existing efforts and creating new ones. Steady growth in interactions and sub-initiatives is expected for the coming years.

\subsubsection{The European Phosphorus Platform}

The European Phosphorus Platform (EPP), currently hosted by the Dutch Nutrient Platform in Den Haag, is a joint initiative of eighty European partners that hold core interests along the phosphorus value chain. It was launched at the European Sustainable Phosphorus Conference in March 2013 via a joint declaration of 150 participants on goals, principles, and next steps [52]. A strong focus rests on improving use efficiency, recycling, creating a market for secondary phosphate products, and improving cooperation between the parties concerned, in the wider scheme of new job creation, retaining competitiveness, and decreasing supply risk [53]. To launch the platform, 40 different stakeholder groups from industry, business, NGOs, and knowledge institutions collaborated with the 
European Commission (EC). The concern about phosphorus scarcity was initially brought to the attention of the EC via a tender report in 2010 [54]. EC's core phosphate activities have recently been focusing on a Green Paper and a consultative communication on P use sustainability [55], the revision of the fertilizer regulation, as well as the Raw Materials Initiative. One focus rests on closing knowledge gaps in regard to phosphate flows in the EU [56]. It has been argued that major willingness by policy-makers is needed to create a EU legal framework that opens a safe space for necessary research and development. Network engagement is open for science and business partners, particularly from Southern and Eastern Europe to gain a more balanced representation.

\section{General Remarks on Developments}

An early driver in the modern phosphorus sustainability movement seems to have been substantial increases in phosphate rock and phosphoric acid prices in 2007/2008 [57] coupled with short- to mid-term supply risk concerns as put forward through the peak concept in Déry and Anderson [9], and later, Cordell, Drangert and White [1]. Although concerns had been raised earlier [58-60], recent developments suggest that a combination of factors in 2007/2008 led to the observed substantial rise in international science and policy awareness. Established magazines such as Nature, Spiegel, and Scientific American [20,61,62] covered developments, with images that were easy to grasp for a large audience. In addition, the inherent fear of civilization decline-to not have phosphate would be nothing short of agricultural suicide-likely helped give the topic attention and momentum. Further, as phosphorus can be easily linked to other concerns of the 21 st century, such as water quality, energy security, land use and climate change, it represents a convincing case to study as a proxy in sustainable resource management.

Assuming that the number of citations a paper receives is a valid proxy for how well it has been received within a given community, the results of the citation analysis generally suggest an activating effect between Cordell, Drangert and White [1] and the beginnings of the phosphorus sustainability movement. This is further supported by GPRI's pioneering role as the first global initiative promoting phosphorus security. Google Scholar search results, and a reflection upon the majority of the initiatives' drivers indicate that scarcity concerns based on an impending peak in rock production or depletion of reserves have become common; this is despite evolved knowledge and data suggesting no such scenario in the foreseeable future. This begs the question of whether some efforts are founded on assumptions that do not reflect current knowledge-A question that is depicted in Figure 4. While no answer is intended on the basis of the information provided, it nevertheless seems necessary to avoid falling back predominantly on the depletion scare when framing reasons for a clear need to improve the management of $\mathrm{P}$ along its value chain [63]. It is important to note that the importance of $\mathrm{P}$ or phosphate rock in agriculture is beyond dispute, and so is the need for more reliable data; however, there seems a need to shift focus on consensus themes instead, such as more efficiency in production, consumption according to needs, (food) waste, or environmental externalities (as depicted in Figure 3). These fields seem of similar or larger interest and point toward equally fertile research topics. Moreover, they may be more manageable points of entry for stronger stakeholder collaboration. 
Figure 4. A cartoonist view: From sustainable phosphorus management to peak P [64].

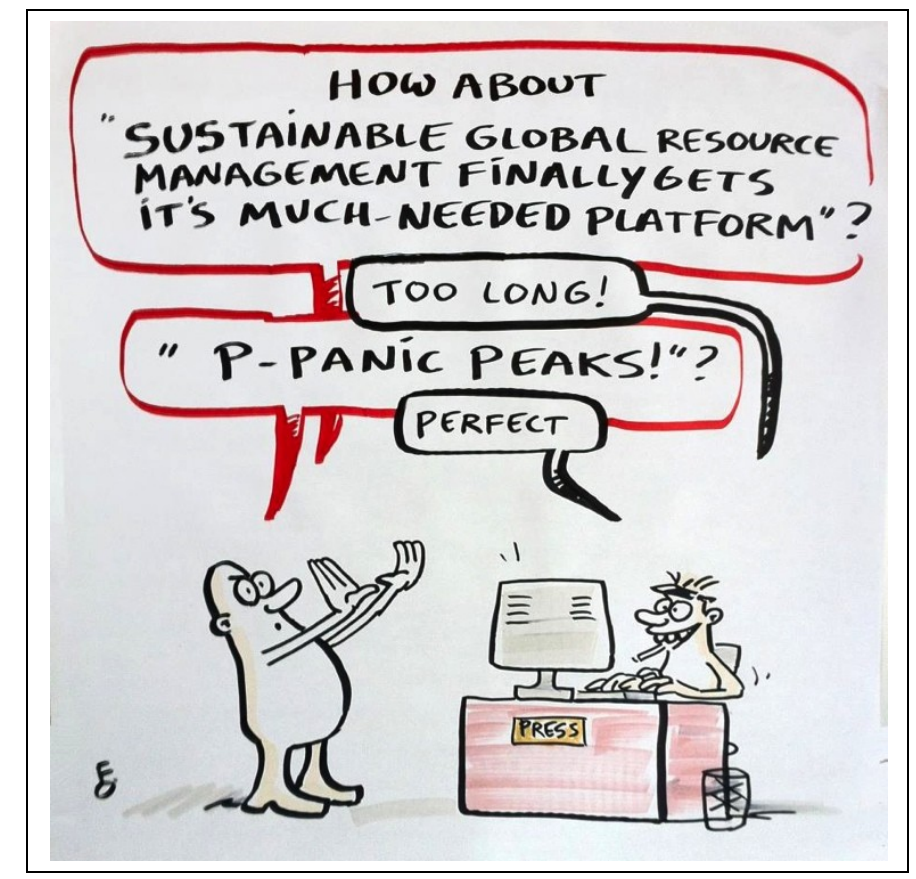

\section{Opportunities and Challenges}

In the following, the results of the profiling analysis are discussed in respect to some general observations about opportunities and challenges within and among the reviewed platforms. The above suggests that each initiative is characterized by a large diversity of both. We reflect on the more prominent ones and place them within the broader debate of the functioning of group efforts concerned with global environmental change as well as their potential impact on national and international levels.

\subsection{Opportunities}

\subsubsection{Improved Understanding}

The growing involvement of a larger and more diverse community of stakeholders can provide for a richer understanding of the phosphorus cycle, its anthropocenic changes, organization of issues, and priority areas of engagement, hence improving the likelihood of more effective and acceptable orientations for future action. This involvement in pool learning and experience building might, by the nature of the process, create new change agents and knowledge brokers who can take the challenge of how to sustainably manage phosphorus beyond a short to medium-term focus. In this "here-to-stay-scenario," it seems important to integrate those sciences that have traditionally been active in the problem field (such as agricultural sciences) more strongly with the human-environment system sciences. Moreover, expertise resulting from projects such as the IGCP Project 156, a decade-long (1977-1988) effort by more than 300 scientists to explore phosphate rock genesis and deposits, or the European Cost Action Project 869, which focused on quantifying the agricultural contribution to eutrophication, seem important to integrate in ongoing efforts to improve the nature and scale of the problem as well as how to approach it. 


\subsubsection{Global Focus}

Independent of the action level, no initiative decouples itself from the reality of the nature of the problem, which is inherently global [65]. This leads to dynamic interactions on many scales between different initiatives. As most include another initiative or representative thereof, ranging from participation in meetings and funding all the way to co-founding other initiatives e.g., the European Phosphorus Platform). Although these inter-and trans-level interactions seem to be currently only loosely structured, they allow for an important exchange between stakeholders in different world regions that might otherwise not naturally interact.

\subsubsection{Transition Processes}

It has been argued that there are no effective institutional set-ups or governance structures for phosphorus [66]. As a consequence, researchers and practitioners turned to their own interim interventions: forming solution-oriented and agenda-setting initiatives that become a starting point for awareness raising, research, and actions to improve use, reuse, and recycling of $\mathrm{P}$. There are, however, risks in solo actions that are disadvantageous to the global community. For example, there are risks involved in individual solutions, such as single countries engaging in independent negotiations for exclusive supply contracts with phosphate rock providers. Hilpert et al. [67] argue that resources problems cannot be solved through unilateralism, yet in the absence of global governance mechanisms or agreements, new paths need to be taken. The authors suggest discussion platforms, more transparency, and stronger coupling of international research and development as possible pathways to follow. In respect to sustainable resource management, it seems, in general, as if there is more to gain from new styles of cooperation, on all levels, than from the possible losses resulting from it.

\subsubsection{Synergies}

Phosphorus is closely related to other resource issues and environmental problem fields of the $21 \mathrm{st}$ century. This cross-learning opportunity needs to be considered in more detail, particularly in the light of duplication efforts and time-management. Platforms such as the International Nitrogen Initiative, The Global Soil Partnership, and the Sustainable Sanitation Alliance offer entry points for expanded learning. Moreover, insights can be gained from coupled problem fields such as those outlined in the UN World Water Development Report 4 [68] or the Hirsch Report [69] on the impacts, mitigation, and risk management of peak oil production.

\subsection{Challenges}

\subsubsection{Stakeholder Cooperation}

As the citation and event mapping results indicate, the majority of research activity to date has concentrated in developed countries, with the exception of China. Moreover, within the pool of initiatives presented, only one originated in the South. Most of the initiatives that strive for a balanced global or regional North-South/East representation acknowledge the challenge inherent in achieving this goal. For example, EPP is actively advocating for stronger participation from Southern and 
Eastern Europe. Beyond the spatial dimension, challenges also exist in sectorial terms, i.e., generating participatory interest on the part of stakeholders from practice. Researchers have yet to explore ways to facilitate greater participation from e.g., the phosphate rock mining and processing industry. Building trust between different stakeholder groups, respecting cross-cultural differences, and finding a common language to speak to ensure effective communication are major challenges, with a severe impact on achieving meaningful inquiry processes into $\mathrm{P}$ sustainability, that, if absent, will dwarf any effort to improving use and reuse [70]. These inherent challenges of interdisciplinary collaboration are well known see e.g., [71,72]; this can also be said of the interaction between science, policy, producers, and civil society [73].

\subsubsection{Problem Evolution}

In order to strengthen the support for these joint efforts, there seems a need to generate greater shared understanding when framing key issues. The question of phosphate rock reserves remains greatly debated, particularly as to whether phosphate rock reserve and resource data should be monitored by a supra-national organization. For strategic resources in general, Lee et al. [74] for example suggested a form of trustee relationship where information would be collected but only made available to a specific consented steward group in an aggregated form. Such an approach may work given that agreement over said procedure can be reached amongst key parties. However, endeavors to improve clarity on the systemic input side should be paralleled by adaptation and risk mitigation strategies that focus on the inefficient or unequal system throughput and social or environmental externalities resulting on the output side (i.e., from waste and losses). Arguably, the sooner the controversial depletion debate shifts towards mismanagement issues (including more intelligible phosphate rock reserve and resources accounting), the more likely we may see a larger diversity of viewpoints engaged and find real solutions [75].

\subsubsection{Knowledge Generation, Impact and Funding}

In order to define the ill-structured problem field of phosphorus sustainability more clearly and find new ways of moving forward, stakeholders have turned towards pooling the fragmented experience and knowledge of a diverse group of actors, often under the header of science-based mutual learning engagement. Although, in general, the need for stronger linkages between science and society finds increasing support, both within the science community [76] as well as from societal stakeholders, successful implementation remains a demanding and often daunting task, from both methodological and operational viewpoints. If and what the new formats of engagement between science and the larger society within the phosphorus domain — often referred to as transdisciplinarity [77] — can deliver, particularly on the global level, remains to be seen. This is also largely related to the fact that understanding of transdisciplinarity ranges from a very loose concept of, e.g., science and practice interaction all the way to a rigorous methodological process approach. The bridge-building function that science can fulfill in such a setting, also referred to as science diplomacy, appears significant. Moreover, supportive mechanisms need to be put in place to ensure that these joint journeys of trial and error will be successful [78]. The question of funding in particular plays an important role. A study by Porter and colleagues [79] on the impact of research coordination networks (RCN) in comparison to 
other funding schemes concluded that RCN support did result in improved networking amongst a research community, increased interdisciplinary, and more influential publications. However, the real-world impact of those studies was not broached. A format of transdisciplinarity may allow for more tangible outcomes on an operational level, yet there are few conventional funding opportunities available. To overcome this bottleneck, science-based networks have turned to innovative multi-source funding schemes. Nonetheless, to provide sufficient resources so that networks can work and produce effectively will remain a challenge in the future. Newly established funding agencies such as the Global Research Council may be able to respond to such dilemmas [80].

\subsubsection{Research Management}

The size and diversity of most initiatives makes them a daunting management task. To establish well-functioning mutual learning and action communities across different scales poses complex requirements for organizers. Differences in problem perception, priority setting, and language are just a few of the challenges. Moreover, the amount of skills such as cultural empathy or patience necessary on the part of participants to reduce tensions should not be underestimated. Further, the growing multitude of initiatives may impair the capacity to create change, as many seek for similar stakeholder involvement or may even compete for funding. Hence, pairing the growing momentum with overarching home infrastructure seems promising, as it may offer a hub where the multiple initiatives can meet for exchange, while at the same time keeping their unique characteristics. Such a metaorganizational structure, perhaps under the umbrella of UNEP GPNM or the International Resource Panel, for instance, has the potential to shift the sometimes sub-optimal conditions in which research, exchange, and debate currently take place towards a more efficient, resource-effective process. Facilitating such a transdisciplinary exchange - suggested as a new format of science-practice crowdsourcing - further has the potential to prevent duplication. Moreover, it may enable bridging the current gap between some of the initiatives, unite efforts, and ultimately provide solutions based on a jointly generated, shared and consolidated knowledge base.

\section{Concluding Remarks}

The aim of this paper was to trace the origin and development of the modern phosphorus sustainability movement and to profile major platforms, including their opportunities and challenges. While the movement was originally started as a joint initiative between two research institutes in Australia and Sweden, it has rapidly evolved into a broadening venture drawing worldwide attention. Nevertheless, it remains largely northern and science-based, with significant potential for improved coupling and coordination on a meta-level. Based on the given observations, and at this critical stage of development, the following steps are proposed:

- To embrace the South and improve stakeholder cooperation from the phosphate rock, fertilizer, food, and feed industry;

- To find a more balanced approach when communicating the major concerns for phosphorus sustainability — of which only one may be regional phosphate rock depletion or declining phosphate rock grade; 
- To generate, through transdisciplinary science-practice cooperation, improved, shared understanding of the underlying problem mechanisms and dynamics;

- To create a repository for continued collective learning on a meta-level for long-term change.

Clearly, this will not be an easy task. However, to address these issues appears as a promising pathway for forming a new culture of cooperative learning and problem solving on a global scale, that, if successful, can lead to lasting solutions.

\section{Acknowledgements}

The authors are grateful to participants of the panel presentation Showcasing sustainable phosphorus platforms during the 3rd Sustainable Phosphorus Summit in Sydney, Australia (2 March 2012). We thank Kazuyo Matsubae, James Elser, and Christopher Thornton for providing additional information on initiatives. We acknowledge Emmanuel Frossard, Pius Krütli, Simone Nanzer, Astrid Oberson, and three anonymous reviewers for their helpful comments, as well as to Sandro Bösch for graphic support. This work has been funded by the Swiss National Science Foundation (Grant CR $1212132374 / 1)$.

\section{Conflicts of Interest}

The authors declare no conflict of interest.

\section{References}

1. Cordell, D.; Drangert, J.-O.; White, S. The story of phosphorus: Global food security and food for thought. Global Environ. Change 2009, 19, 292-305.

2. Adams, J. Collaborations: The rise of research networks. Nature 2012, 490, 335-336.

3. Global reach. Available online: http://www.nature.com/news/global-reach-1.11592 (accessed on 21 October 2013).

4. Merriam Webster Online Dictionary. Available online: http:/www.merriam-webster.com/ dictionary/movement (accessed on 19 October 2013).

5. King, F.H. Farmers of Forty Centuries, or Permanent Agriculture in China, Korea and Japan. Available online: http://www.ipcp.org.br/References/Solos/FarmersofFortyCenturies.pdf (accessed on 18 October 2013).

6. Jasinksi, S.M. Potash Statistics and Information. Mineral Commodity Summaries, U.S. Geological Survey, January 2013. Available online: http://minerals.usgs.gov/minerals/pubs/ commodity/potash/ (accessed on 14 September 2013)

7. Apodaca, L.E. Sulfur. Statistics and Information. Mineral Commodity Summaries, U.S. Geological Survey, January 2012. Available online:http://minerals.usgs.gov/minerals/ pubs/commodity/sulfur/mcs-2012-sulfu.pdf (accessed on 27 March 2013).

8. Ott, H. Fertilizer Markets and Their Interplay with Commodity and Food Prices; European Commission: Seville, Spain, 2012.

9. Déry, P.; Anderson, B. Peak phosphorus. Available online: http://www.resilience.org/stories/ 2007-08-13/peak-phosphorus (accessed on 19 October 2013). 
10. Hubbert, K.M. Nuclear Energy and the Fossil Fuels. Available online: http://www.resilience.org/ stories/2006-03-08/nuclear-energy-and-fossil-fuels (accessed on 19 October 2013).

11. Jasinski, S.M. Phosphate Rock Statistics and Information. Available online: http://minerals.usgs.gov/ minerals/pubs/commodity/phosphate_rock/ (accessed on 15 February 2013).

12. Hubbert, M.K. Energy from Fossil Fuels. Science 1949, 109, 103-109.

13. SciVerse Scopus Paper citation analysis and result analysis. Available online: http://www.scopus.com (accessed on 19 October 2013).

14. Van Kauwenbergh, S.J. World Phosphate Rock Reserves and Resources. Available online: http://pdf.usaid.gov/pdf_docs/PNADW835.pdf (accessed on 19 October 2013).

15. Mew, M. Future Phosphate Rock Production-Peak or Plateau? Available online: http://www.ferteconfrc.info/page15.htm (accessed on 19 October 2013).

16. Debunking Ten Myths about Phosphate Rock Production Trends from 1992-2011; IFA: Paris, France, 2012.

17. Vaccari, D.A.; Strigul, N. Extrapolating phosphorus production to estimate resource reserves. Chemosphere 2011, 84, 792-797.

18. Scholz, R.W.; Wellmer, F.W. Approaching a dynamic view on the availability of mineral resources: What we may learn from the case of phosphorus? Global Environ. Change 2013, 23, 11-27.

19. Elser, J.; Bennett, E. Phosphorus cycle: A broken biogeochemical cycle. Nature 2011, 478, $29-31$.

20. Gilbert, N. The disappearing nutrient. Nature 2009, 461, 716-718.

21. Vaccari, D.A. Chemosphere phosphorus cycle issue-Introduction. Chemosphere 2011, 84, 735-736.

22. Vaccari, D.A. The phosphorus cycle. Chemosphere 2011, 84, 735-854.

23. Matsubae-Yokoyama, K.; Kubo, H.; Nakajima, K.; Nagasaka, T. A Material Flow Analysis of Phosphorus in Japan. J. Ind. Ecol. 2009, 13, 687-705.

24. Matsubae, K.; Kajiyama, J.; Hiraki, T.; Nagasaka, T. Virtual phosphorus ore requirement of Japanese economy. Chemosphere 2011, 84, 767-772.

25. Kuroda, A.; Takiguchi, N.; Gotanda, T.; Nomura, K.; Kato, J.; Ikeda, T.; Ohtake, H. A simple method to release polyphosphate from activated sludge for phosphorus reuse and recycling. Biotechnol. Bioeng. 2002, 78, 333-338.

26. Metson, G.S.; Bennett, E.M.; Elser, J.J. The role of diet in phosphorus demand. Environ. Res. Lett. 2012, 7, doi:10.1088/1748-9326/7/4/044043.

27. Ulrich, A.E.; Cordell, D.; Corman, J.; Smit, B. Showcasing Sustainable Phosphorus Platforms. Presente at The 3rd Sustainable Phosphorus Summit, Sydney, Australia, 2 March 2012.

28. Childers, D.L.; Corman, J.; Edwards, M.; Elser, J.J. Sustainability challenges of phosphorus and food: Solutions from closing the human phosphorus cycle. BioScience 2011, 61, 117-124.

29. Phoenix Phosphorus Declaration Concensus Statement. In Proceedings of Sustainable Phosphorus Summit, Tempe, AZ, USA, 3-5 February 2011.

30. Wyant, K.A.; Corman, J.E.; Elser, J.J. Phosphorus, Food, and Our Future; Oxford University Press: New York, NY, USA, 2013.

31. Phosphate Value Chain Agreement. Available online: http://www.nutrientplatform.org/ images/download/Dutch_phosphate_value_chain_agreement_-_Oct_4th_2011.pdf (accessed on 19 October 2013). 
32. National Strategic Phosphorus Advisory Group. Availabe online: http://phosphorusfutures.net/ files/NSPAG ToR_v1-2_300512.pdf(accessed on 18 February 2013).

33. Cordell, D.; Jackson, M.; White, S. Phosphorus flows through the Australian food system: Identifying intervention points as a roadmap to phosphorus security. Environ. Sci. Pol. 2013, 29, 87-102.

34. Cordell, D.; Schmid Neset, T.; White, S.; Drangert, J.-O. Preferred Future Phosphorus Scenarios: A Framework for Meeting Long-Term Phosphorus Needs for Global Food Demand. In International Conference on Nutrient Recovery From Wastewater Streams Vancouver, 2009; IWA Publishing: London, UK, 2009.

35. Statutes of the Global Phosphate Forum. Available online: http://phosphate-forum.org/downloads/ ENGLISH\%20Forum\%20signed\%20statutes\%203-5-07.pdf (accessed on 18 October 2013).

36. EP Supports Ban of Phosphates in Consumer Detergents. Available online: http://europa.eu/rapid/press-release_IP-11-1542_en.htm (accessed on 21 October 2013).

37. Cordell, D. The Story of Phosphorus: Sustainability Implications of Global Phosphorus Scarcity for Food Security. Available online: http://iu.diva-portal.org/smash/get/diva2:291760/ FULLTEXT01.pdf (accessed on 21 October 2013).

38. Declaration on Global Phosphorus Security. Available online: http://phosphorusfutures.net/ files/GPRI_2009_Declaration_P_Security.pdf (accessed on 18 October 2013).

39. Cordell, D.; Rosemarin, A.; Schroder, J.J.; Smit, A.L. Towards global phosphorus security: A systems framework for phosphorus recovery and reuse options. Chemosphere 2011, 84, 747-758.

40. Cordell, D.; White, S. Peak phosphorus: Clarifying the key issues of a vigirous debate about longterm phosphorus security. Sustainability 2011, 3, 2027-2049.

41. UNEP Yearbook 2011: Emerging Issues in our Global Environment. Available online: http://www.unep.org/yearbook/2011/pdfs/UNEP_YEARBOOK_Fullreport.pdf (accessed on 18 October 2013).

42. United Nations Environment Programme. The Global Partnership on Nutrient Management Availabe online: http://www.unep.org/ecosystemmanagement/Portals/7/Documents/factsheets/ GPNM\%20FactSheet\%20web.pdf (accessed on 19 October 2013).

43. UNEP Manila Declaration on Furthering the Implementation of the Global Programme of Action for the Protection of the Marine Environment from Land-based Activities. Available online: http://www.gpa.depiweb.org (accessed on 19 October 2013).

44. Our Nutrient World: The challenge to produce more food and energy with less pollution. Available online: http://www.gpa.unep.org/index.php/global-partnership-on-nutrient-management/ (accessed on 19 October 2013).

45. Eilittä, M.; Scholz, R.W.; Roy, A.H.; Ulrich, A.E.; Hellums, D.T. The Global TraPs Project Transdisciplinary processes for sustainable phosphorus management. Available online: http://www.globaltraps.ch/tl_files/pdf/projectdocs/GT_Brochure_105.pdf (accessed on 18 October 2013).

46. Scholz, R.W.; Ulrich, A.E.; Eilittä, M.; Roy, A. Sustainable use of phosphorus: A finite resource. Sci. Total Environ. 2013, doi: 10.1016/j.scitotenv.2013.05.043. 
47. Allenby, B.; Burt, D.; Dumas, M.; Heffer, P.; Hu, Z.; Scholz, R.W.; Springer, N.; Ulrich, A.E.; Vaccari, D.A.; Wellmer, F.-W. Global TraPs Workshop Propositions. In Proceedings of The 2nd Phosphorus Summit, Tempe, AZ, USA; 4 March 2011. Available online: http://www.globaltraps.ch/ tl_files/pdf/newsletters/GT_Newsletter_2.pdf (accessed 21 October 2013).

48. Scholz, R.W.; Amit, R.; Ulrich, A.E.; Eilittä, M.; Hellums, D. transdisciplinary processes for sustainable phosphorus management (2010-2015). Available online: http://www.globaltraps.ch/ tl_files/pdf/newsletters/GT_Newsletter_4.pdf (accessed on 18 October 2013).

49. Scholz, R.W.; Roy, A.; Brand, F.; Hellums, D.; Ulrich, A.E. Sustainable Phosphorus Management: A Global Transdisciplinary Roadmap; Springer: Dordrecht, Netherlands, 2013; in press.

50. GFS Final Report. Available online: http://www.globalfoodsecurityforum.com/lang/content_en/ downloads/GFSF2012_EN.pdf (accessed on 19 October 2013).

51. GFS Global Food Security Forum. Mission Statement and Key Principles. Available online: http://www.globalfoodsecurityforum.com/2012/en/home (accessed on 19 October 2013).

52. European Phosphorus Platform. Available online: http://www.phosphorusplatform.eu (accessed on 19 October 2013).

53. De Ridder, M.; de Jong, S.; Polchar, J.; Lingemann, S. Risks and Opportunities in the Global Phosphate Rock Market. Robust Strategies in Times of Uncertainty. Available online: http://www.phosphorusplatform.eu/images/download/HCSS_17_12_12_Phosphate.pdf (accessed on 18 October 2013).

54. Schröder, J.J.; Cordell, D.; Smit, A.L.; Rosemarin, A. Sustainable Use of Phosphorus.Available online: http://ec.europa.eu/environment/natres/pdf/sustainable_use_phosphorus.pdf (accessed on 18 October 2013).

55. European Commission. Communication from the Commission to the European Parliament, the Council, the European Economic and Social Committee and the Committee of the Regions. Available online: http://ec.europa.eu/europe2020/pdf/nd/2013eccomm_en.pdf (accessed on 18 October 2013).

56. Ott, C.; Rechberger, H. The European phosphorus balance. Resour. Conserv. Recy. 2012, 60, 159-172.

57. Historical Price Trends. Fertil. Int. 2012, issue November December, 4.

58. Steen, P. Phosphorus availablity in the 21st century: management of a nonrenewable resource. Phosphorus Potassium 1998, 217, 25-31.

59. Abelson, P.H. A Potential Phosphate Crisis. Science 1999, 283, 2015.

60. Rosemarin, A. The precarious geopolitics of phosphorous. Available online: http://www.susana.org/ docs_ccbk/susana_download/2-338-rosemarin-2004-precarious-geopolitics-phosphorus-cse-en.pdf (accessed on 18 October 2013).

61. Vaccari, D.A. Phosphorus: A looming crisis. Sci. Am. 2009, 300, 54-59.

62. Schmundt, H. Asche zu Asche. Der Spiegel 2010, 15, 136-137 (in German).

63. Van Kauwenbergh, S.J.; Stewart, M.; Mikkelsen, R. World reserves of phosphate rock...a dynamic and unfolding story. Available online: http:/www.ipni.net/publication/bettercrops.nsf/ 0/C3AB0523A890EBC685257BD50055E09A/\$FILE/BC\%202013-3\%20p18.pdf (accessed on 18 October 2013). 
64. Oudshoorn, F. The cartoonist perspective on Phosphorus. ESPC 2013. Available online: http://www.phosphorusplatform.org/ (accessed on 19 October 2013).

65. Rockström, J. A safe operating space for humanity. Nature 2009, 461, 472-475.

66. Cordell, D. Phosphorus: The Story of Phosphorus: Sustainability Implications of Global Phosphorus Scarcity for Food Security. Ph.D. Thesis, Linkoping University, Linkoping, Sweden, 2010.

67. Hilpert, H.G.; Mildner, S.-A. Nationale Alleingänge oder internationale Kooperation? Available online: http://www.swp-berlin.org/fileadmin/contents/products/studien/2013_S01_hlp_mdn.pdf (accessed on 18 October 2013).

68. WWAP. Managing Water under Uncertainty and Risk; The United Nations World Water Development Report 4 Volume 1; WWAP: Paris, France, 2012.

69. Hirsch, R.L.; Bezdek, R.; Wendling, R. Peaking of World Oil Production: Impacts, Mitigation, and Risk Managment. Available online: http://www.netl.doe.gov/publications/others/pdf/ oil_peaking_netl.pdf (accessed on 18 October 2013).

70. Ulrich, A.E.; Stauffacher, M.; Krütli, P.; Schnug, E.; Frossard, E. Response to the comments on "Tackling the phosphorus challenge: Time for reflection on three key limitations". Environ. Dev. 2013, in press.

71. Mooney, H.A.; Duraiappah, A.; Larigauderie, A. Evolution of natural and social science interactions in global change research programs. Proc. Natl. Acad. Sci. USA 2013, doi: 10.1073/pnas.1107484110.

72. Stokols, D.; Hall, K.L.; Taylor, B.K.; Moser, R.P. The Science of Team Science: Overview of the Field and Introduction to the Supplement. Am. J. Prev. Med. 2008, 35, S77-S89.

73. Bergmann, M.; Jahn, T.; Knobloch, T.; Krohn, W.; Pohl, C.; Schramm, E. Methods for Transdisciplinary Research: A Primer for Practice; Campus Verlag: Frankfurt, Germany, 2012.

74. Lee, B.; Preston, F.; Kooroshy, J.; Bailey, R.; Lahn, G. Resources Futures. Availabe online: http://www.chathamhouse.org/sites/default/files/public/Research/Energy,\%20Environment\%20an d\%20Development/1212r_resourcesfutures.pdf (accessed on 18 October 2013).

75 Ulrich, A.E.; Stauffacher, M.; Krütli, P.; Schnug, E.; Frossard, E. Tackling the phosphorus challenge: Time for reflection on three key limitations. Environ. Dev. 2013, in press.

76. On a new era of global science. World Science Forum Declaration of the Budapest World Science Forum 2011. Availabe online. http://www.sciforum.hu/declaration/index.html (accessed on 19 October 2013).

77. Hirsch Hadorn, G.; Hoffmann-Riem, H.; Biber-Klemm, S.; Grossenbacher-Mansuy, W.; Joye, D.; Pohl, C.; Wiesmann, U.; Zemp, E.E. Handbook of Transdisciplinary Research; Springer: Berlin, Germany, 2008.

78. Pahl-Wostl, C.; Giupponi, C.; Richards, K.; Binder, C.; de Sherbinin, A.; Sprinz, D.; Toonen, T.; van Bers, C. Transition towards a new global change science: Requirements for methodologies, methods, data and knowledge. Environ. Sci. Policy 2013, 28, 36-47.

79. Porter, A.L.; Garner, J.; Crowl, T. Research Coordination Networks: Evidence of the Relationship between Funded Interdisciplinary Networking and Scholarly Impact. BioScience 2012, 62, 282-288. 
80. Suresh, S. Research funding: Global challenges need global solutions. Nature 2012, 490, 337-338.

(C) 2013 by the authors; licensee MDPI, Basel, Switzerland. This article is an open access article distributed under the terms and conditions of the Creative Commons Attribution license (http://creativecommons.org/licenses/by/3.0/). 